\title{
Сун Пэн
}

Российские композиторы в репертуаре современных китайских пианистов

С целью исследования особенностей и характера обращения к русской фортепианной музыке китайских пианистов анализируются дискография китайских фортепианных звезд и программы концертов выпускников Пекинской консерватории. Сопоставление данных говорит о влиянии китайских виртуозов на своих младших коллег, а также о предпочтениях произведений Чайковского, Рахманинова, Прокофьева и Скрябина. Делается вывод о том, что музыка русских композиторов близка китайским музыкантам и изучается ими, а также о том, что этот выбор обусловлен технической сложностью композиций.

Адрес статьи: www.gramota.net/materials/9/2020/4/37.html

\section{Источник}

\section{Манускрипт}

Тамбов: Грамота, 2020. Том 13. Выпуск 4. С. 183-189. ISSN 2618-9690.

Адрес журнала: www.gramota.net/editions/9.html

Содержание данного номера журнала: www.gramota.net/materials/9/2020/4/

\section{( ) Издательство "Грамота"}

Информация о возможности публикации статей в журнале размещена на Интернет сайте издательства: www.gramota.net Вопросы, связанные с публикациями научных материалов, редакция просит направлять на адрес: hist@gramota.net 
Список источников

1. Апатский В. Н. Основы теории и методики духового музыкально-исполнительского искусства. К.: НМАУ имени П. И. Чайковского, 2006. 430 с.

2. Апатский В. Н. Очерки истории духового исполнительства. Прошлое и проблемы наших дней // Дослідження. Досвід. Спогади: збірка наукових праць / ред. В. Шерстюк. К., 2004. Вип. 5. С. 103-114.

3. Блажевич В. М. Школа игры для раздвижного тромбона. М.: Муз. сектор Гос. изд-ва, 1925. 83 с.

4. Болотин С. В. Биографический словарь музыкантов-исполнителей на духовых инструментах. Л.: Музыка, 1969. 201 с.

5. Гайдамович Т. А. Мастера игры на духовых инструментах Московской консерватории. М.: Музыка, 1979. 189 с.

6. Григорьев Б. П. В. М. Блажевич - тромбонист, педагог, дирижер. М.: Музыка, 1979. 181 с.

7. Крижанівський Ф. П. Український концерт для тромбона в аспекті становлення та розвитку жанру: дис. ... к. мистецтвознавства. Одеса, 2006. 204 с.

8. Левин С. Я. Духовые инструменты в истории музыкальной культуры. Л.: Музыка, 1973. 124 с.

9. Усов Ю. А. История отечественного исполнительства на духовых инструментах. М.: Музыка, 1988. Ч. 1. 262 с.; Ч. 2. 190 с.

10. Черных А. В. Советское духовое инструментальное искусство. М.: Сов. композитор, 1989. 320 с.

\title{
Trombone Expressive Means in V. M. Blazhevich's Concerts
}

\author{
Latyshev Nikolai Ivanovich \\ Belgorod State Institute of Arts and Culture \\ latishev.1966@icloud.com
}

The article examines three most popular concerts for trombone of the outstanding performer and founder of the Russian trombone school V. M. Blazhevich. Relying on the analysis of the concert opuses, the researcher identifies peculiarities of using the expressive and technical potential of the solo instrument. The paper focuses on the following issues: the factors that influenced popularity of the compositions under study, types of thematism, specificity of the harmonic approach, nuances of compositional arrangement and the performer's means of expressiveness.

Key words and phrases: V. M. Blazhevich; trombone; concert for trombone; trombone expressive means; compositional peculiarities of concerts for trombone; composer's and performer's means of expressiveness.

УДК 78; 786

https://doi.org/10.30853/manuscript.2020.4.37

Дата поступления рукописи: 10.02.2020

С иелью исследования особенностей и характера обращения к русской фортепианной музыке китайских пианистов анализируются дискография китайских фортепианных звезд и программы кониертов выпускников Пекинской консерватории. Сопоставление данных говорит о влиянии китайских виртуозов на своих младших коллег, а также о предпочтениях произведений Чайковского, Рахманинова, Прокофьева и Скрябина. Делается вывод о том, что музыка русских композиторов близка китайским музыкантам и изучается ими, а также о том, что этот выбор обусловлен технической сложностью композиций.

Ключевые слова и фразы: русские композиторы; китайские пианисты; репертуарные предпочтения; репертуар; Ланг Ланг; Ван Юйцзя.

\section{Сун Пэн}

Российский государственный педагогический университет имени А. И. Герцена, г. Санкт-Петербург songpeng036@qq.com

\section{Российские композиторы в репертуаре современных китайских пианистов}

Истоки китайской фортепианной школы берут своё начало в русской фортепианной традиции [1, с. 22-24; 13 , с. $8 ; 15$, с. 24-30]. Однако благодаря «политике открытости» [10], начатой в Китае в 1978 году, и в связи с быстрым экономическим развитием китайский пианизм стал обогащаться и другими притоками - в частности, западноевропейской и американской фортепианной культурой. Став за последние двадцать лет ХХ века по-настоящему массовым, фортепианное образование в Китае сформировало плеяду блестящих современных пианистов, которые начиная с 1990-х годов побеждают в международных конкурсах и знакомят мир с достижениями китайской фортепианной школы [11, с. 59]. Таким образом, имея прочный фундамент освоенных традиций великих европейских фортепианных школ и продолжая развитие своей национальной самобытности, китайский пианизм уверенно вышел на международную арену, а потому изучение некоторых тенденций в репертуарной политике современных китайских пианистов представляется актуальным.

Как известно, для художественно-выразительной интерпретации музыкального произведения необходимо исследовать стилевые черты его автора, культурную среду и эпоху создания этой композиции. Поэтому по количеству исполняемых произведений русских композиторов в репертуаре китайских пианистов можно 
косвенно судить о том, насколько знакома русская культура современным китайским виртуозам, а значит, и миллионам китайских музыкантов, которые слушают и стремятся подражать своим кумирам. Таким образом, основной целью данной статьи является анализ того, какова степень близости и понимания русской культуры современными китайскими музыкантами и на какой основе строится диалог музыкальных культур России и Китая. Такая постановка проблемы, а также сочетание количественного и качественного подходов в ее разрешении составляют научную новизну в рамках изучения репертуарной политики современных китайских пианистов.

Для достижения поставленной цели статьи было выбрано два подхода. В рамках первого нами анализируется дискография пяти современных и наиболее популярных в Китае и в мире пианистов (по версии сайта Ranker vote on [17] и китайской энциклопедии Baidu [16]), имеющих на своем счету записанные и выпущенные альбомы (например, у такого прославленного пианиста, как Конг Сяндун (Xiang-Dong Kong), есть только один записанный альбом, и тот посвящен китайской фортепианной музыке) и в чьем репертуаре есть музыка русских композиторов (например, в дискографии такого известного современного китайского пианиста, как Сунь Юнди (Sun Yingdi), присутствуют только произведения Ф. Листа) (см. Табл. 1). В рамках второго подхода анализируются интервью и высказывания о произведениях русских композиторов двух современных китайских пианистов (Ван Юйцзя и Ланг Ланг), наиболее известных в мире, в чьих репертуарах представлено наибольшее количество русской музыки.

Таблица 1. Список произведений русских композиторов в репертуаре знаменитых китайских пианистов (см. Приложение)

\begin{tabular}{|c|c|c|}
\hline № & $\begin{array}{l}\text { Китайские } \\
\text { пианисты }\end{array}$ & $\begin{array}{c}\text { Произведения русских композиторов, имеющиеся в репертуаре } \\
\text { (год выпуска альбома) }\end{array}$ \\
\hline 1 & $\begin{array}{l}\text { Yuja Wang } \\
\text { (Ван Юйцзя) }\end{array}$ & $\begin{array}{l}\text { Рахманинов С. В. Концерт № } 2 \text { до минор для фортепиано с оркестром, ор. } 18 \text { (альбом } 2011 \text { го- } \\
\text { да выпуска) } \\
\text { Рахманинов С. В. Рапсодия на тему Паганини ля минор, ор. } 43 \text { (альбом } 2011 \text { года выпуска) } \\
\text { Рахманинов С. В. Этюды-картины, ор. } 39 \text {, № } 6 \text {, ля минор; № 4, си минор; № 5, ми-бемоль } \\
\text { минор (альбом } 2012 \text { года выпуска) } \\
\text { Рахманинов С. В. Элегия ми-бемоль минор, ор. } 3 \text {, № } 1 \text { (альбом } 2012 \text { года выпуска) } \\
\text { Рахманинов С. В. Концерт № } 3 \text { ре минор для фортепиано с оркестром, ор. } 30 \text { (альбом } 2013 \text { го- } \\
\text { да выпуска) } \\
\text { Скрябин А. Н. Фортепианная соната № } 2 \text {, соль-диез минор, ор. } 19 \text { (Соната-фантазия) (альбом } \\
2009 \text { года выпуска) } \\
\text { Скрябин А. Н. } 24 \text { прелюдии для фортепиано, ор. } 11 \text {, № } 11 \text {, си мажор и № 12, соль-диез минор; } \\
6 \text { прелюдий, ор. } 13 \text {, № 6, си минор (альбом } 2012 \text { года выпуска) } \\
\text { Скрябин А. Н. } 12 \text { этюдов для фортепиано, ор. } 8, \text { № } 9 \text {, до-диез минор; } 2 \text { поэмы, ор. } 32 \text { Поэма } \\
\text { № } 2 \text {, фа-диез минор (альбом } 2012 \text { года выпуска) } \\
\text { Стравинский И. Ф. Три фрагмента из балета «Петрушка», переложенные композитором } \\
\text { для фортепиано (альбом } 2010 \text { года выпуска) } \\
\text { Прокофьев С. С. Концерт № } 2 \text { соль минор для фортепиано с оркестром, ор. } 16 \text { (альбом } 2013 \text { го- } \\
\text { да выпуска) }\end{array}$ \\
\hline 2 & $\begin{array}{l}\text { Lang I } \\
\text { (Ланг }\end{array}$ & $\begin{array}{l}\text { Чайковский П. И. Концерт № } 1 \text { си-бемоль минор для фортепиано с оркестром, ор. } 23 \text { (аль- } \\
\text { бом } 2003 \text { года выпуска) } \\
\text { Рахманинов С. В. Концерт № } 2 \text { до минор для фортепиано с оркестром, ор. } 18 \text { (альбом } 2005 \text { го- } \\
\text { да выпуска) } \\
\text { Рахманинов С. В. Концерт № } 3 \text { ре минор для фортепиано с оркестром, ор. } 30 \text { (альбом } 2002 \text { го- } \\
\text { да выпуска) } \\
\text { Рахманинов С. В. Рапсодия на тему Паганини ля минор, ор. } 43 \text { (альбом } 2005 \text { года выпуска) } \\
\text { Скрябин А. Н. Этюд, ор. 2, № } 1 \text {, до-диез минор; } 12 \text { этюдов для фортепиано, ор. } 8, \text { № } 2 \text {, фа- } \\
\text { диез минор, № } 3 \text {, си минор, № } 8 \text {, ля-бемоль мажор, № } 10 \text {, ре-бемоль мажор, № } 11 \text {, си-бемоль } \\
\text { минор, № } 12 \text {, ре-диез минор; } 8 \text { этюдов для фортепиано, ор. } 42 \text {, № } 4 \text {, фа-диез мажор, № } 3 \text {, фа- } \\
\text { диез мажор; } 3 \text { этюда для фортепиано, ор. } 65 \text {, № } 3 \text {, соль мажор (альбом } 2002 \text { года выпуска) } \\
\text { Прокофьев С. С. Концерт № } 3 \text { до мажор для фортепиано с оркестром, ор. } 26 \text { (альбом } 2013 \text { года } \\
\text { выпуска) }\end{array}$ \\
\hline 3 & $\begin{array}{l}\text { Li Yul } \\
\text { (Ли Ю }\end{array}$ & $\begin{array}{l}\text { Прокофьев C. С. Концерт № } 2 \text { соль минор для фортепиано с оркестром, op. } 16 \text { (альбом } 2008 \text { го- } \\
\text { да выпуска) } \\
\text { Прокофьев C. С. Концерт № } 2 \text { соль минор для фортепиано с оркестром, оp. 16, 2. Скерцо (Vivace) } \\
\text { (альбом } 2013 \text { года выпуска) }\end{array}$ \\
\hline 4 & $\begin{array}{l}\text { Sa Chen } \\
\text { (Са Чен) }\end{array}$ & $\begin{array}{l}\text { Мусоргский М. П. Картинки с выставки (альбом } 2009 \text { года выпуска) } \\
\text { Мусоргский М. П. Ночь на Лысой горе (альбом } 2009 \text { года выпуска) } \\
\text { Рахманинов С. В. Этюды-картины, ор. 39, № 1, до минор; № 2, ля минор; № 3, фа-диез минор; } \\
\text { № 4, си минор; № 5, ми-бемоль минор; № 6, ля минор (альбом } 2009 \text { года выпуска) } \\
\text { Рахманинов С. В. Концерт № } 2 \text { до минор для фортепиано с оркестром, ор. } 18 \text { (альбом } 2011 \text { го- } \\
\text { да выпуска) }\end{array}$ \\
\hline 5 & $\begin{array}{l}\text { Chu-Fang Huang } \\
\text { (Хуан Чуфан) }\end{array}$ & $\begin{array}{l}\text { Рахманинов С. В. Соната № 2, си-бемоль минор, ор. } 36 \text { (альбом } 2005 \text { года выпуска) } \\
\text { Прокофьев С. С. Соната № 7, си-бемоль мажор, ор. } 83 \text { (альбом } 2005 \text { года выпуска) }\end{array}$ \\
\hline
\end{tabular}

Можно заметить, что все альбомы выпущены в 2000-х годах, что связано в первую очередь с тем, что китайские пианисты начали работать со звукозаписывающими студиями только после того, как стали мировыми знаменитостями, т.е. сравнительно недавно. Как видно из Таблицы 1, наиболее представлены в репертуаре 
китайских пианистов произведения С. В. Рахманинова (в особенности его Концерты для фортепиано с оркестром № 2 и № 3) и произведения С. С. Прокофьева (Концерт для фортепиано с оркестром № 2). Особенностью русского репертуара Ланг Ланга является также наличие Концерта № 1 для фортепиано с оркестром П. И. Чайковского, а репертуар Се Чан украшен «Картинками с выставки» М. П. Мусоргского. Наибольшее внимание привлекает к себе относительно объемный русский репертуар Ван Юйцзя, в чьем арсенале находятся произведения А. Н. Скрябина и И. Ф. Стравинского.

Для того чтобы определить, насколько результаты исследования дискографий современных звезд китайского пианизма соответствуют предпочтениям в русской музыке других китайских музыкантов, мы обратились к репертуару молодого китайского поколения пианистов и выбрали для этого выпускников Китайской музыкальной консерватории (г. Пекин). Являясь одним из лучших музыкальных вузов КНР, консерватория Китая готовит профессионалов высокого уровня и всегда находится в авангарде культурной жизни страны [4, с. 240]. Именно поэтому репертуар концертов, проведенных в разных городах Китая в рамках художественной практики выпускников факультета фортепиано Китайской музыкальной консерватории (г. Пекин), можно определить как репрезентабельный и сравнить его с репертуаром китайских звезд мирового уровня.

Из 15 концертов, сыгранных в промежутке между 2016 и 2018 годами, только в программах 7 из них (см. Табл. 2) присутствовали произведения русских композиторов. Чаще всего в концертном репертуаре выпускников встречалась музыка таких европейских композиторов, как Моцарт, Лист, Шопен, и музыка китайских композиторов, например, таких как Лю Цин, Чжан Цзыцзян, Чэнь Ичжэнь, Чжан Шуйа и др.

Таблица 2. Произведения русских композиторов, исполняемые студентами фортепианного отделения музыкальной консерватории Китая на концертах художественной практики (материалы собраны на официальном сайте Музыкальной консерватории Китая (г. Пекин))

\begin{tabular}{|l|l|l|}
\hline \multicolumn{1}{|c|}{ № } & \multicolumn{1}{|c|}{ Дата концерта } & \multicolumn{1}{|c|}{ Произведения русских композиторов, исполняемые на концерте } \\
\hline 1 & 21 апреля 2016 года & Прокофьев С. С. Сарказмы, пять пьес для фортепиано, ор. 17 \\
\hline 2 & 25 июня 2016 года & $\begin{array}{l}\text { Чайковский П. И. Из цикла «Времена года» картины: «Июнь. Баркарола» и «Ноябрь. } \\
\text { На тройке» }\end{array}$ \\
\hline 3 & 22 апреля 2017 года & $\begin{array}{l}\text { Прокофьев С. С. Сюита (предположительно Вальсы Шуберта, выбранные и объеди- } \\
\text { нённые в сюиту) } \\
\text { Рахманинов С. В. Этюды-картины, ор. } 33\end{array}$ \\
\hline 4 & 28 июня 2017 года & $\begin{array}{l}\text { Рахманинов С. В. Сюита № 2, ор. } 17 \\
\text { Рахманинов С. В. Шесть пьес, ор. } 11, \text { № } 1 \text { (Баркарола) }\end{array}$ \\
\hline 5 & 30 апреля 2018 года & Скрябин А. Н. Фантазия си минор, ор. 28 \\
\hline 6 & 18 мая 2018 года & Рахманинов С. В. Этюды-картины, ор. 39, № 1 \\
\hline 7 & 2 ноября 2018 года & $\begin{array}{l}\text { Скрябин А. Н. } 12 \text { этюдов для фортепиано, ор. } 8 \text { № } 10 \text { ре-бемоль мажор } \\
\text { Прокофьев С. С. Аллегро ре минор, ор. 2, № } 1\end{array}$ \\
\hline
\end{tabular}

Как это видно из приведенной таблицы, студенты Пекинской консерватории обращаются к творчеству тех же русских композиторов, что и их старшие коллеги. При этом надо заметить, что из-за концертного регламента (в течение 1,5-2 часов выступают от 7 до 12 человек) ими выбираются произведения малой формы.

Таким образом, можно прийти к выводу, что по большей части в репертуаре современных китайских пианистов представлены русские композиторы, чье творчество вошло в золотой фонд фортепианной музыки: Чайковский, Рахманинов, Прокофьев, Скрябин. При этом можно предположить наличие влияния, которое оказывают на выбор репертуара начинающих музыкантов уже состоявшиеся звезды китайского пианизма, что подтверждается, во-первых, докторским исследованием С. А. Айзенштадта (специалист в области дальневосточных фортепианных школ) [3, с. 14], а во-вторых, природой китайского «фортепианного бума» [12, с. 167].

Так, Айзенштадт, рассматривая структуру коммуникации в рамках фортепианных школ Дальневосточного региона, подчеркивает, что «на национальном уровне значимость фигуры лидера-исполнителя для консолидации школы выступает особенно ярко» [3, с. 15]. Выделяя два коммуникационных канала лидерского влияния - «педагог - учащийся» и «исполнитель - последователь», - Айзенштадт замечает, что именно последний воспринимается как образец для подражания [Там же, с. 14].

О подражании же речь идет в обсуждении причин «фортепианного бума», т.е. невероятно высокого спроса на фортепианное образование, которое стало по-настоящему массовым и пришлось на начало XXI века. Основной же причиной подобной популярности фортепиано в Китае, наряду с важностью изучения музыки в конфуцианской традиции и престижностью музыкального образования, является возможность сделать блестящую мировую карьеру. Эта сторона китайского фортепианного бума даже получила особое название «эффект Ланг Ланга» [12, с. 167]. Как пишет Сюй Бо, «организацией карьеры Ланг Ланга был нанесен удар по системе фортепианных кумиров и авторитетов: весь мир, благодаря такой мощной коммерциализации артиста в сфере классической музыки, должен был по-новому посмотреть на пианистов из стран, не имеющих ни традиций, ни школы игры на рояле. Эффект получился двойной: “окрылил” саму страну и способствовал укреплению престижа рояля в мировой музыкальной культуре» [Там же]. Таким образом, начинающие пианисты, желая повторить успех своих кумиров, активно осваивают тот репертуар, который исполняется китайскими звездами мирового уровня, а значит, русская фортепианная музыка, представленная произведениями Чайковского, Рахманинова, Прокофьева и Скрябина, близка китайским музыкантам и осваивается ими.

Во второй части исследования мы обратились к содержательному анализу декларируемого отношения к русской музыке самых известных китайских пианистов, входящих в список лучших исполнителей мира, 
а именно Ланг Ланга и Ван Юйцзя. Кроме того, выбор данных исполнителей продиктован активной публичной жизнью этих светил китайского пианизма, что позволяет собрать наиболее представительный материал для анализа. Стоит особо оговорить, что третий наиболее известный китайский пианист Ли Юньди не подошел для исследования в силу ограниченности его русского репертуара (основное кредо исполнителя - Шопен).

Ланг Ланг родился в 1982 году в городе Шэньян (провинция Мукден). Обучаться игре начал в трехлетнем возрасте, а уже в 5 и 7 лет два раза подряд занял первое место на Шэньянском детском конкурсе пианистов. В 11 лет одержал победу в группе профессиональных исполнителей на Пятом всекитайском детском и юношеском конкурсе пианистов «Кубок Синхай». В том же 1993-м завоевал первое место на Четвертом международном конкурсе молодых пианистов в Германии, а в 1995 году одержал победу на Втором международном конкурсе молодых музыкантов имени П. И. Чайковского [8, с. 147].

С 1996 года обучался у Гэри Граффмана, поступив в американский Кертис-институт (Curtis Institute of Music), и в том же году подписал контракт с международной продюсерской компанией IMG, а некоторое время спустя перешел к Deutsche Grammophon Gesellschaft. Мировую известность пианисту принес 1999 год, когда он в возрасте 17 лет заменил заболевшего Андре Ваца и выступил совместно с Чикагским симфоническим оркестром, исполнив Первый концерт П. И. Чайковского (дирижер В. Эшенбах). После этого выступления американская газета “Chicago Tribune” написала: «Лан Лан - величайший гений в мире, вызывающий потрясение фортепианный самородок» [Цит. по: Там же, с. 148], а такая газета, как “The New York Times”, назвала его «самым ярким исполнителем классической музыки» [11, с. 60]. На сегодняшний день Ланг Ланг является международным послом доброй воли ЮНИСЕФ, культурным послом в Китае от Национальной академии искусства и науки звукозаписи США, в 2009 году был включен журналом “Тіте” в список ста наиболее влиятельных людей года и в том же году введен в Зал славы журнала “Gramophone” [8, с. 147-148].

В случае с прославленным Ланг Лангом важным моментом в процессе знакомства с музыкой русских композиторов стала его базовая подготовка, опирающаяся на традиции русской фортепианной школы. Отвечая на вопрос корреспондента о том, какую музыкальную школу он предпочитает, музыкант замечает: «Я вырастал на русской школе, потому что все учителя в своё время сами учились в Советском Союзе. Когда я приехал в США, там у меня тоже был учитель с русской школой. Но позже в Европе я познакомился и с немецкой, и с итальянской, и с другими школами. Я считаю, что очень хорошо уметь играть Чайковского и Прокофьева с помощью методологии русской школы, а Бетховена - немецкой» [7].

Как мы уже отмечали выше, восхождение 17-летнего Ланг Ланга на вершину мирового успеха началось именно с исполнения Первого концерта Чайковского, когда он, заменив заболевшего музыканта, сыграл его с Чикагским симфоническим оркестром. Но восхищенные отзывы были и после исполнения Второго концерта Рахманинова в 2004 году, когда немецкая газета "Der Spiegel” сравнила китайского пианиста с Горовицем. К слову, в том же 2004-м Ланг Ланг был признан в Германии лучшим исполнителем года.

Просматривая страницы биографии китайского виртуоза, можно еще не раз встретить свидетельства триумфа, которого он достигал, исполняя музыку русских композиторов. И это не удивительно. Как замечает Айзенштадт, «высшие творческие достижения крупных представителей китайской, японской, корейской пианистической культуры связаны по преимуществу не с опусами национальных композиторов, а с вошедшими в “золотой фонд” мирового фортепианного репертуара сочинениями западноевропейских, русских и др. авторов» [2, с. 184]. Кроме того, по мысли того же С. А. Айзенштадта, интерес Ланг Ланга к русской музыке является следствием предпочтений его американского учителя Г. Граффмана, учившегося у В. Горовица [Там же, с. 185].

Таким образом, сочетание природного дара и знакомства с русской фортепианной традицией позволяет известному китайскому пианисту проникать и раскрывать миры русских композиторов. Сближает Ланг Ланга с русской музыкой и то, что стиль его исполнения ближе к романтизму. Именно этот стиль отвечает китайскому музыкальному мышлению, «стремящемуся к подвижной, текучей, переменчивой и таинственной беспредельности» [Там же, с. 186]. Текучесть преобладает и в исполнительском ощущении формы, и в дыхании. Кроме того, характерной чертой агогики является изощренная дробность, отражающая частую смену оттенков эмоционального состояния. Исполнительской же артикуляции китайских пианистов свойственна скорее мягкая связность, в то время как «туше и педализация устремлены к красочности и прозрачности тембра» [Там же, с. 185-186].

На сегодняшний день еще более прославленным китайским пианистом является такая исполнительница, как Ван Юйцзя (в другой транскрипции имя пишется как Юя Ванг). Ван Юйцзя родилась в Пекине в 1987 году, учиться музыке начала сравнительно поздно (только в 6 лет). Однако уже в 7 лет поступила в Центральную консерваторию музыки в Пекине, а в 11 - была зачислена в Mount Royal College Conservatory (Канада), где училась у профессора Хун-Куан Чена. Позже исполнительница совершенствовала свои навыки у Гэри Граффмана (у которого ранее учился Ланг Ланг) в Кертисовском институте музыки в Филадельфии, который окончила в 2008 году [5].

Свою концертную карьеру Ван Юйцзя начала в 14 лет с выступления в Карнеги-холл. С тех пор артистка успешно выступает в самых престижных залах Европы, Азии и Северной Америки, работая с ведущими оркестрами и выдающимися мастерами (Клаудио Аббадо, Даниэль Баренбойм, Зубин Мета, Майкл Тилсон Томас, Густаво Дудамель, Валерий Гергиев, Юрий Темирканов и др.) [Там же]. С 2009 года китайская пианистка подписала контракт с лейблом "Deutsche Grammophon”, и уже несколько ее альбомов были номинированы на «Грэмми». Как пишет газета "Los Angeles Times”, «ее легкая, блестящая виртуозность сделала бы честь Прокофьеву (который был великим пианистом) и даже легендарному Горовицу» [Цит. по: Там же]. 
В интервью Ван Юйцзя можно видеть ее любовь к русской музыке и знание русской музыкальной культуры. Описывая свои ощущения от исполнения Третьего концерта Рахманинова для фортепиано с оркестром, пианистка говорит: «Наверное, самый счастливый момент для меня, когда я выхожу на сцену. Я сажусь за инструмент, и рождается музыка, настолько пронзительная, искренняя и настолько русская, что я исполняю ее на одном дыхании. Мне это напоминает русский роман с его сложными персонажами и неожиданными поворотами сюжета» [6]. Можно заметить, что высказывание Ван Юйцзя демонстрирует ее знакомство с русской литературой, а если это так, то вся русская (в том числе музыкальная) культура воспринимается ею в более широком охвате. Ведь именно всестороннее погружение в культурный контекст позволяет понять культурные коды и проникнуться ценностным и смысловым своеобразием русского мира [14, с. 189].

Еще более содержательны ее комментарии ко Второму концерту Прокофьева: «У меня особенная близость с Прокофьевым - он очень ускользающий, саркастичный, временами почти злой, не признающий авторитетов... Для меня Второй концерт значит очень много. Мне кажется, я впервые услышала его лет в 14, и помню, как меня буквально сбила с ног волна этой мощной, очень плотной музыки высочайшего эмоционального накала. У Прокофьева очень концентрированная музыка. Каждая деталь произведения важна для раскрытия конфликтующего сознания композитора. Когда я играю эту музыку, мне кажется, я ведьму в руки беру. И по мере игры она исторгает языки пламени, крутится, пытается ускользнуть. Меня завораживает эта темная, загадочная сторона Прокофьева, эта его фантасмагория. Музыка настолько сильна, что почти беспокоит слушателя, но именно это меня в ней притягивает... Думаю, любой музыкант стремится к совершенству, которое не в отсутствии фальшивых нот, мы ведь не машины. А в достижении того особого проникновения в мир музыки, который чувствует слушатель и который так его трогает... В наших руках возможность ошеломить аудиторию, стать проводником музыкального замысла. Именно к этому я стремлюсь...» [6].

Можно предположить, что проникнуть в гений Прокофьева Ван Юйцзя помогает исключительно развитая музыкальная интуиция и психологическая близость к русскому композитору. Можно с осторожностью предположить, что восприятие музыки Прокофьева для китайской пианистки в какой-то степени лишено национального налета, ведь, по словам исполнительницы, музыка Прокофьева - это «чистый Rock’n‘Roll» [9]. Столь вызывающая оценка творчества русского композитора, вероятно, говорит о внимании пианистки к некоторой агрессивности, дерзости и авангардизму музыки Прокофьева. Безусловно, в этом своем проявлении Ван Юйцзя далека от культа уравновешенности и эмоциональной сдержанности, свойственных конфуцианскому миросозерцанию, часто приписываемому китайским пианистам [3].

При этом исполнительский стиль Ван Юйцзя также можно отнести к романтизму особого китайского типа, который С. А. Айзенштадт назвал «восточным романтизмом». Для китайской пианистки свойственно чувственное ощущение красоты музыки, то ощущение прекрасного, о котором говорит Ло Шин, описывая китайскую эстетику как рожденную от физических органов чувств, как испытываемую «на вкус» [2, с. 187].

Подводя итог, приходится согласиться с мнением С. А. Айзенштадта, который считает, что репертуарные предпочтения крупных китайских виртуозов соответствуют основным мировым тенденциям [Там же, с. 185]. Кроме этого, необходимо отметить, что репертуар любого музыканта - это исключительно вопрос вкуса. Однако из проведенного исследования можно сделать вывод, что знание творчества русских композиторов - это почти обязательное условие для успешной карьеры исполнителя, а потому неудивительно, что китайские пианистывиртуозы хорошо знают русскую музыку. Указанные в исследовании репертуарные предпочтения, свойственные китайским пианистам, скорее говорят об общем стремлении виртуозов показать все свои технические возможности, ведь, например, концерты и Рахманинова, и Прокофьева чрезвычайно сложны технически. Таким образом, в стремлении завоевать мировое признание, китайские пианисты активно осваивают русский репертуар и часто, обучаясь в рамках русской традиции или в какой-то степени касаясь ее, хорошо понимают осваиваемые произведения. Как бы то ни было, говорить об особой специфике русского репертуара китайских пианистов пока нельзя, но необходимо отметить значительное место русской фортепианной музыки на мировой сцене.

\section{Приложение}

Таблица 3. Выходные данные альбомов, упомянутых в Таблице 1

\begin{tabular}{|l|c|l|}
\hline Китайские пианисты & № альбома & \multicolumn{1}{c|}{ Выходные данные альбома } \\
\hline $\begin{array}{l}\text { Yuja Wang } \\
\text { (Ван Юйцзя) }\end{array}$ & 1 & $\begin{array}{l}\text { Название альбома: Sonatas \& Etudes } \\
\text { Год выпуска: 2009 } \\
\text { Лейбл: Deutsche Grammophon }\end{array}$ \\
\cline { 2 - 3 } & 2 & $\begin{array}{l}\text { Название альбома: Transformation } \\
\text { Год выпуска: 2010 } \\
\text { Лейбл: Deutsche Grammophon }\end{array}$ \\
\cline { 2 - 3 } & \multirow{2}{*}{3} & $\begin{array}{l}\text { Название альбома: Rachmaninov } \\
\text { Год выпуска: 2011 } \\
\text { Лейбл: Deutsche Grammophon }\end{array}$ \\
\cline { 2 - 4 } & \multirow{2}{*}{4} & $\begin{array}{l}\text { Название альбома: Fantasia } \\
\text { Год выпуска: 2012 } \\
\text { Лейбл: Deutsche Grammophon }\end{array}$ \\
\cline { 2 - 4 } & \multirow{2}{*}{5} & $\begin{array}{l}\text { Название альбома: Piano Concertos / Rachmaninov, Prokofiev } \\
\text { Год выпуска: 2013 } \\
\text { Лейбл: Deutsche Grammophon }\end{array}$ \\
\hline
\end{tabular}




\begin{tabular}{|c|c|c|}
\hline Китайские пианисты & № альбома & Выходные данные альбома \\
\hline \multirow[t]{4}{*}{$\begin{array}{l}\text { Lang Lang } \\
\text { (Ланг Ланг) }\end{array}$} & ( & $\begin{array}{l}\text { Название альбома: Rachmaninoff: Piano Concerto № } 3 \text { / Scriabin: Etudes } \\
\text { Год выпуска: } 2002 \\
\text { Лейбл: Telarc }\end{array}$ \\
\hline & 2 & $\begin{array}{l}\text { Название альбома: Tchaikovsky, Mendelssohn: First Piano Concertos } \\
\text { Год выпуска: } 2003 \\
\text { Лейбл: Deutsche Grammophon }\end{array}$ \\
\hline & 3 & $\begin{array}{l}\text { Название альбома: Rachmaninov: Piano Concerto № 2; Paganini Rhapsody } \\
\text { Год выпуска: } 2005 \\
\text { Лейбл: Deutsche Grammophon }\end{array}$ \\
\hline & 4 & $\begin{array}{l}\text { Название альбома: Prokofiev: Piano Concerto № } 3 \text { - Bartók: Piano Concerto № } 2 \\
\text { Год выпуска: } 2013 \\
\text { Лейбл: Sony Classical }\end{array}$ \\
\hline \multirow[t]{2}{*}{$\begin{array}{l}\text { Li Yundi } \\
\text { (Ли Юньди) }\end{array}$} & 1 & $\begin{array}{l}\text { Название альбома: Yundi Li: Sergei Prokofiev Piano Concerto № } 2 \text { \& Ravel } \\
\text { Piano Concertos in G Major } \\
\text { Год выпуска: } 2008 \\
\text { Лейбл: Deutsche Grammophon }\end{array}$ \\
\hline & 2 & $\begin{array}{l}\text { Название альбома: The art of YUNDI } \\
\text { Год выпуска: } 2013 \\
\text { Лейбл: Deutsche Grammophon }\end{array}$ \\
\hline \multirow[t]{2}{*}{$\begin{array}{l}\text { Sa Chen } \\
\text { (Са Чен) }\end{array}$} & 1 & $\begin{array}{l}\text { Название альбома: Rachmaninov - } 6 \text { Etudes Tableaux \& Mussorgsky - Pictures } \\
\text { at an Exhibition \& A Night on Bald Mountain } \\
\text { Год выпуска: } 2009 \\
\text { Лейбл: PENTATONE PTC }\end{array}$ \\
\hline & 2 & $\begin{array}{l}\text { Название альбома: Rachmaninov \& Grieg - Piano Concertos. Sa Chen, Law- } \\
\text { rence Foster, Gulbenkian Orchestra } \\
\text { Год выпуска: } 2011 \\
\text { Лейбл: PENTATONE PTC }\end{array}$ \\
\hline \multirow[t]{2}{*}{$\begin{array}{l}\text { Chu-Fang Huang } \\
\text { (Хуан Чуфан) }\end{array}$} & 1 & $\begin{array}{l}\text { Название альбома: Van Cliburn International Piano Competition Semifinal Round } \\
\text { Год выпуска: } 2005 \\
\text { Лейбл: Van Cliburn Foundation }\end{array}$ \\
\hline & 2 & $\begin{array}{l}\text { Название альбома: Van Cliburn International Piano Competition Preliminary Round } \\
\text { Год выпуска: } 2005 \\
\text { Лейбл: Van Cliburn Foundation }\end{array}$ \\
\hline
\end{tabular}

Список источников

1. Айзенштадт С. А. О роли русской фортепианной школы в процессе художественного формирования пианистического искусства Китая и Японии // Исторические, философские, политические и юридические науки, культурология и искусствоведение. Вопросы теории и практики. 2015. № 3 (53). Ч. І. С. 22-27.

2. Айзенштадт С. А. Стилевые искания в фортепианном исполнительстве стран Дальневосточного региона // Проблемы музыкальной науки. 2011. № 2 (9). С. 184-188.

3. Айзенштадт С. А. Фортепианные школы стран Дальневосточного региона (Китай, Корея, Япония). Проблемы теории, истории, исполнительской практики: автореф. дисс. ... д. иск. Новосибирск, 2015. 49 с.

4. Айзенштадт С. А., Исаева Н. Г. Обучение китайских студентов в классе специального фортепиано. Из опыта Дальневосточного государственного института искусств // Манускрипт. 2019. № 11. С. 239-244.

5. Ван Юйцзя [Электронный ресурc]. URL: https://www.meloman.ru/performer/van-yujczya/ (дата обращения: 03.05.2019).

6. Ван Юйщзя: о Прокофьеве, ведьмах и шоколаде [Электронный ресурc]. URL: https://www.youtube.com/ watch?v=tGO-N0iL 5Y (дата обращения: 10.03.2019).

7. Волкова Н. Самый популярный пианист мира Ланг Ланг: «Я вырастал на русской школе» [Электронный ресурс]. URL: http://ptel.cz/2012/04/samyj-populyarnyj-pianist-mira-lang-lang-ya-vyrastal-na-russkoj-shkole/ (дата обращения: 10.03.2019).

8. Ло Чжихуэй. Лан Лан: страницы биографии // Известия Российского государственного педагогического университета им. А. И. Герцена. 2013. № 160. С. 146-151.

9. Пианистка Ван Юйцзя: по стопам Сергея Прокофьева [Электронный ресypc]. URL: https://www.classicalmusicnews.ru/ interview/Pianistka-Van-Juiczja-po-stopam-Sergeja-Prokofeva/ (дата обращения: 10.03.2019).

10. Политика реформ и открытости [Электронный ресурc]. URL: https://ru.wikipedia.org/wiki/Политика_реформ и_открытости (дата обращения: 03.05.2019).

11. Сюй Бо. Китайские пианисты на рубеже XX-XXI веков: исполнительские достижения и система обучения // ЮжноРоссийский музыкальный альманах. 2011. № 1. С. 59-68.

12. Сюй Бо. Китайский «Фортепианный бум» в начале XIX века // Вестник Адыгейского государственного университета. Серия 2. Филология и искусствоведение. 2011. № 2. С. 165-169.

13. Сюй Бо. Феномен фортепианного исполнительства в Китае на рубеже XX-XXI веков: дисс. ... к. иск. Ростовна-Дону, 2011. 149 с.

14. Хань Мо, Юдин А. П. Традиции русской фортепианной школы и современная практика обучения в музыкальных учебных заведениях КНР // Преподаватель ХХІ век. 2017. № 2. Ч. 1. С. 187-198.

15. Хуан Пин. Влияние русского фортепианного искусства на формирование и развитие китайской пианистической школы: дисс. ... к. иск. СПб., 2008. 160 с.

16. https://wapbaike.baidu.com/theme/中国最具影响力九大钢琴家, 郎朗李云迪齐上榜! /49801069213?bk_fr=lemma (дата обращения: 14.02.2019).

17. https://www.ranker.com/list/best-pianists-in-the-world/ranker-music?page=4 (дата обращения: 14.02.2019). 


\title{
The Russian Composers in Repertoire of the Modern Chinese Pianists
}

\author{
Song Peng \\ The Herzen State Pedagogical University of Russia, Saint Petersburg \\ songpeng036@qq.com
}

To identify specificity of the Chinese pianists' interpretation of the Russian piano music, the author analyses discography of the Chinese piano stars and repertoire of Beijing Conservatoire graduates. Influence of the Chinese virtuosi on their junior colleagues is traced. A comparative analysis indicates that Tchaikovsky, Rachmaninoff, Prokofiev and Skriabin are among the most frequently performed composers. Conclusions are made that the Chinese musicians like the Russian music and study it eagerly, and the choice of compositions is conditioned by their technical difficulty.

Key words and phrases: Russian composers; Chinese pianists; repertoire preferences; repertoire; Lang Lang; Wang Yuja.

УДК 7.03; 786

https://doi.org/10.30853/manuscript.2020.4.38

Дата поступления рукописи: 10.02.2020

Многообразие иностранных влияний на китайский пианизм не составляет единой системы и потому не позволяет интегрировать полученный опыт в современное фортепианное образование Китая. На базе анализа различных периодизаций развития китайской фортепианной культуры «волны» влияния были систематизированы, что позволило выявить основные характерные черты подходов к реализачии профессионального фортепианного образования, все еще применяемых в Китае по отдельности, и наметить путь их интеграиции в иеелостную педагогическую систему: техническая база, аналитический подход к изучаемым композициям, научно-теоретическая основа преподавания, изучение образиов пианистического мастерства.

Ключевые слова и фразы: Китай; музыкальное искусство; китайский пианизм; фортепианное образование; профессиональное образование; иностранное влияние; фортепианная школа.

\section{Чэнь Янань}

Российский государственный педагогический университет имени А. И. Гериена, г. Санкт-Петербург 182206256@qq.com

\section{Историческая роль иностранных фортепианных школ в развитии китайского пианизма}

Профессиональное фортепианное образование в Китае в том виде, в каком оно известно сегодня, зародилось только в первой трети XX века и формировалось под интенсивным влиянием иностранных фортепианных традиций, что естественно в связи с привнесённостью пианистической культуры в Китай, почти не знавший этого музыкального инструмента до конца XIX века. При этом современная китайская система профессиональной подготовки пианистов все еще находится на стадии становления, а потому проблема поиска оснований для разработки методической базы, программ обучения и учебных пособий представляется актуальной. Кроме этого, актуальность данного поиска обеспечивается и стремлением китайских специалистов найти теоретико-методологическую основу, которая способствовала бы конкурентоспособности китайской фортепианной школы на мировой арене.

На недостатки китайской педагогической системы и на значимость европейской традиции в освоении фортепианного искусства указывает то, что современные китайские звезды пианизма, для того чтобы проявить себя на престижных международных конкурсах, как правило, едут обучаться в зарубежные музыкальные центры (чаще всего в Германию, Францию или США). Безусловно, бездумное копирование западной традиции без ее адаптации к китайской специфике не ведёт к подлинному совершенствованию пианистической культуры. При этом нельзя забывать, что без иностранного влияния становление китайского пианизма было бы невозможно.

Представляется, что оптимальный путь, по которому в дальнейшем пойдет китайская фортепианная школа, можно обнаружить, обратившись к истории профессионального фортепианного образования в Китае и проследив характер и специфику влияния иностранных пианистических традиций, заложивших фундамент китайского пианизма, что и является целью данной статьи.

Научная новизна исследования обеспечивается подходом, позволяющим соотнести разные «волны» иностранного влияния на китайскую фортепианную культуру с этапами ее исторического развития, что даёт возможность не только определить очаги влияния, но и охарактеризовать степень их воздействия. Тем самым практической значимостью являются систематизация результатов влияния иностранных фортепианных школ и определение основы, на которой в дальнейшем возможно будет строить новые методические разработки фортепианной педагогики.

При этом необходимо учесть, что периодизация китайского пианизма вариабельна. Впрочем, это обстоятельство имеет положительное значение, так как позволяет увидеть историческую перспективу с различной 